\title{
Magnetostratigraphic study of the Melka Kunture archaeological site (Ethiopia) and its chronological implications
}

\author{
Endale Tamrat $^{\mathrm{a}, *}$, Nicolas Thouveny ${ }^{\mathrm{a}}$, Maurice Taieb ${ }^{\mathrm{a}}$, J.P. Brugal ${ }^{\mathrm{b}}$ \\ ${ }^{a}$ Aix-Marseille Université, CNRS, IRD-CEREGE UMR 34-Pole Environnement Arbois Méditérranée, BP 80, 13545 Aix-en-Provence Cedex 4, France \\ ${ }^{\mathrm{b}}$ Aix-Marseille Université, CNRS, UMR 7269 LAMPEA, F-13094 Aix-en-Provence, France \\ A magnetostratigraphy is established for the Melka Kunture archaeological site of Ethiopia, whose \\ chronological setting needed improvement. The magnetostratigraphy is constructed from four distinct \\ stratigraphic sections, Garba-IV (5 sites), Gombore-I (21 sites), Gombore-II (8 sites), and Simbiro (13 \\ sites). Natural remanent magnetizations (NRM) were measured and analyzed over a total of 214 speci- \\ mens to isolate the characteristic components of magnetization and determine magnetic polarities. Two \\ magnetization components were isolated in every sample analyzed: (i) a low-temperature (low coer- \\ civity) secondary normal component and (ii) a high-temperature characteristic component of normal or \\ reversed polarity and allows to identify five magnetozones (N1eR1eN2eR2eN3). Rock magnetic anal- \\ ysis attests that the magnetization is carried by magnetite or titanomagnetite within the range of \\ pseudo-single domain grain sizes. Anisotropy of magnetic susceptibility (AMS) supports a sedimentary \\ origin of the magnetic remanence. Based on recent ${ }^{40} \mathrm{Ar} /{ }^{39} \mathrm{Ar}$ geochronological dating of the site, faunal \\ constraints and a magnetostratigraphic pattern, the sequence is correlated to the time between the early \\ Matuyama chron (<1.80 Ma) and early Brunhes chron (w0.709 Ma) of the geomagnetic polarity time \\ scale (GPTS). Completing recent ${ }^{40} \mathrm{Ar} /{ }^{39} \mathrm{Ar}$ age series, the magnetostratigraphy study presented here \\ allows computation of interpolated ages for various faunal and artifact findings at Melka Kunture and \\ similar fossiliferous deposits in the region.
}

\section{Introduction}

The fossil faunal and cultural rich sequence of Melka Kunture (MK) archaeological site was first recognized in 1963 by Gerard Dekker, who reported the lower Palaeolithic industry collections (Dekker, 1964; Bailloud, 1965). In 1965, a Franco-Ethiopian mission led by Jean Chavaillon began a systematic exploration of the area that lasted until 1995. During this extensive study, a great number of localities contributed to the bulk collection of fossil materials have been discovered. Because of its size, number of sites discovered, abundant archaeological and faunal findings, the Melka Kunture site has been considered as one of the most important areas for studying the evolution of Paleolithic cultures from the Oldowan to the Late Stone Age (LSA) in East Africa (Chavaillon, 1967, 1973; Hours, 1971; Chavaillon and Berthelet, 2004).

Preliminary correlations of the Melka Kunture sequence with other east African faunal sequences had been established based on

* Corresponding author.

E-mail addresses: tamratewm@gmail.com, atamrat@yahoo.com (E. Tamrat). radiometric ages, biostratigraphy and preliminary magnetostratigraphy (Chavaillon, 1973; Schmitt et al., 1977; Westphal et al., 1979; Cressier, 1980). The numerical chronology of the lower part of the MK sequence was derived from conventional KeAr dating of

wide-spread local marker tuffs (Schmitt et al., 1977), and recently from ${ }^{40} \mathrm{Ar} /{ }^{39} \mathrm{Ar}$ dating yielding a maximum age of ca $1.73 \mathrm{Ma}$ for a

tuff in the Garba-IV section, and a minimum age of ca $0.71 \mathrm{Ma}$ for a tuffaceous horizon of Gombore-II section (Morgan et al., 2012). Due to the limitations of the radiometric dating, partly due to possible contamination of the dated minerals, few detailed geochronolog-ical studies were published.

The paucity of numerical dating and lack of well developed magnetostratigraphy of these sites were probably related to the difficulty of finding materials suitable for radiometric dating and

the very weak magnetization of sediments. However, the advent of ${ }^{40} \mathrm{Ar} /{ }^{39} \mathrm{Ar}$ techniques for dating young small samples using a laser

beam to melt the material (Lo Bello et al., 1987) and the new gen-eration of sensitive cryogenic magnetometers (Fuller et al.. 1985) allowed study of volcanic-sedimentary formations. Thus, a 
sequences such as the Olduvai Gorge (Walter et al., 1991), Hadar Formation (Renne et al., 1993; Walter and Aronson, 1993), and other anthropological sites in East Africa (Deino and Potts, 1990). In the past two decades, magnetostratigraphy was thus combined with radiometric dates (KeAr and ${ }^{40} \mathrm{Ar} /{ }^{39} \mathrm{Ar}$ ) to establish robust correlations of the East African hominid and archaeological sequences with the GPTS (e.g. Renne et al., 1993; Walter and Aronson, 1993; Tamrat et al., 1995, 1996; Tamrat, 1997). As part of our regional magnetostratigraphic studies in the middle and lower parts of the Awash basin (Ethiopia), we sampled the Plio-Pleistocene sedimentary sequence of the Melka Kunture archaeological site from two locations (four laterally separated sections), and present here the detailed magnetostratigraphy.

\section{Geological setting and sampling}

The Melka Kunture archaeological site $\left(842.34^{\circ} \mathrm{N}, 3835.94^{\circ} \mathrm{E}\right)$ is located $50 \mathrm{~km}$ southwest of Addis Ababa on the Ethiopian plateau at w2000 m altitude (Fig. 1). The Paleolithic rich deposits were cut by the Awash River at a distance of $50 \mathrm{~km}$ from its source (Taieb,

1974). The $30 \mathrm{~m}$ thick volcano-sedimentary formation consists of fluvial deposits (pebbles, sands, clays) interbedded with volcanic tuffs (cinerites), that constitute wide-spread correlation markers that provided appropriate K-rich minerals for K/Ar (Schmitt et al., 1977), and ${ }^{40} \mathrm{Ar} /{ }^{39} \mathrm{Ar}$ dating (Morgan et al., 2012).

The stratigraphy of the deposits was established by Chavaillon (1971), Taieb (1974), and Chavaillon and Berthelet (2004). The sections investigated for magnetostratigraphy belong to four major sections: Garba-IV, Gombore-I, Gombore-II, and Simbiro. Chavaillon (1971) correlated these four major sections using stratigraphic position of four marker tuffs, labeled A, B, C and D, from the oldest to the youngest (Fig. 2). Erosional phases are documented between the preserved sedimentary cycles (Chavaillon and Taieb, 1968; Chavaillon, 1973; Taieb, 1974; Chavaillon et al., 1978) and linked to major climatic/paleoenvironmental changes revealed by palynological studies (Bonnefille, 1972, 1976).

During a field trip in December 1993, we collected oriented samples from 52 sites across the four major sections of unweathered fine grained sediment facies. The sampled blocks were removed from the outcrop after orientation by using a magnetic compass and immediately wrapped to avoid contamination during transport. The volume of the samples varies with rock facies, usually between 30 and $100 \mathrm{~cm}^{3}$ and were cut to multiple cubic specimens for standard paleomagnetic measurements. Summary of the stratigraphy of the different sections and the position of the paleomagnetic samples are presented in Fig. 2. The geology together with the paleomagnetic sample positions of each sampled sections is discussed below. This stratigraphic classification is based on our field work and is in agreement with previous studies.

\subsection{Garba-IV section}

The Garba-IV section, a well studied prehistoric section, is $2 \mathrm{~m}$ from the river bank (Fig. 1). This topographic position enabled the exposure of various archaeological remains in a small ravine (Piperno and Piperno, 1975). Garba-IV is about 3 e5 $\mathrm{m}$ thick and consists of clay, tuffaceous and minor amounts of sandy layers. Palaeofauna collected from Garba-IV point to a correlation with the lower part of the Gombore-I section. Palaeomagnetic samples were collected at four levels (sites) separated by stratigraphic intervals of $80 \mathrm{~cm}$ to $1 \mathrm{~m}$ (sites GA3eGA6, Fig. 2), from clay, sandy-clay and a tuffaceous layer.

\subsection{Gombore-I section}

The Gombore-I section is located a few meters away from the Awash river, and consists of clayey tuff deposit interbedded in greenish clays and sands (Fig. 1). A northesouth trending fault dipping SE (2e5) cuts the deposits, overlain by the present day sedimentary units. 23 levels (G0eG15J, Fig. 2) were sampled in tuffaceous and clayey layers, $30 e 50 \mathrm{~cm}$ intervals over a total thickness of about $13 \mathrm{~m}$.

\subsection{Gombore-II section}

The Gombore-II section, located south of the Gombore-I section, is $\mathbf{w} 10 \mathrm{~m}$ thick. Sandy and clayey layers are dominant in its lower part and interbedded with $20 \mathrm{~cm}$ thick volcanic tuffs, that constitute correlation markers with the upper Gombore-I section (Fig. 2). The middle and upper part is composed of clay, sands, conglomerates and a sandy-clayey deposits overlain by the present day sediments. Ten paleomagnetic levels were sampled (G16eG24, Fig. 2) at $50 \mathrm{~cm}$ to $2 \mathrm{~m}$ intervals.

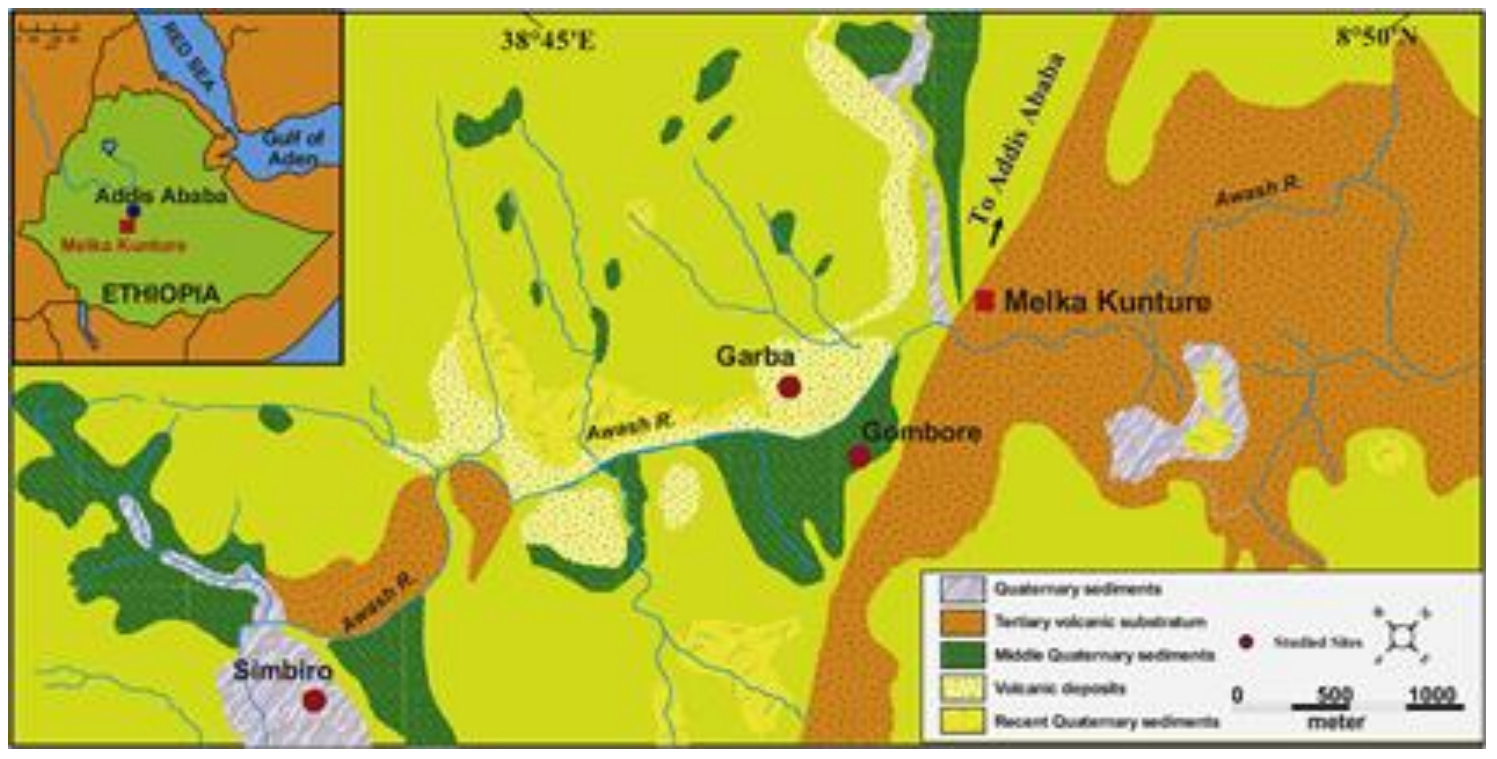

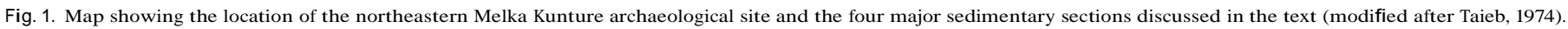




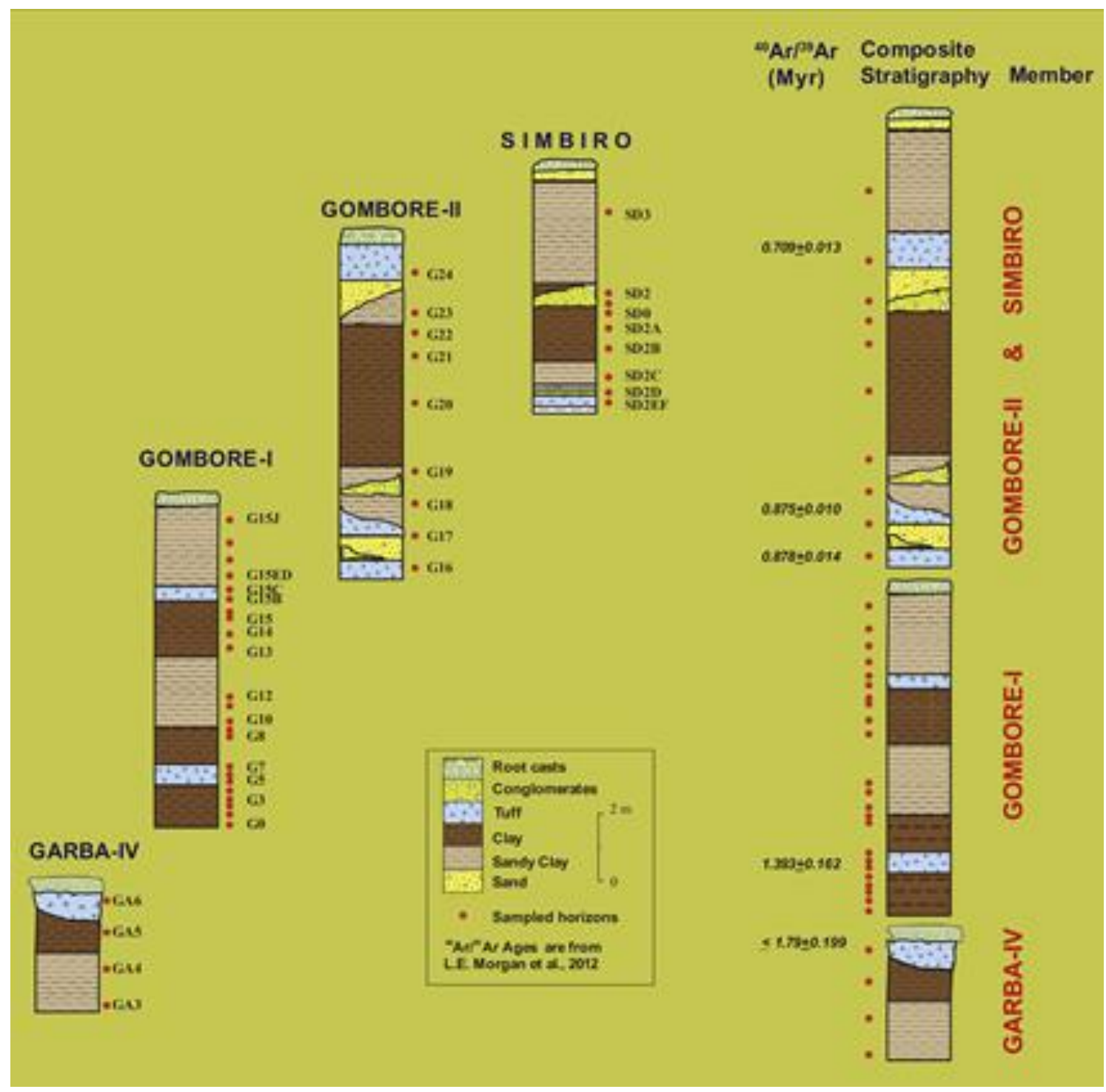

Fig. 2. Schematized stratigraphic sequence, composite section, and sampling locations of the Melka Kunture archaeological localities.

\subsection{Simbiro section}

The Simbiro section is located $2 \mathrm{~km}$ south of the other three sections and consists of $\mathbf{W} 15 \mathrm{~m}$ of unconsolidated sediments (Figs. 1 and 2). The upper part is composed of clays, tuffs, sandy-clay and gravels and the middle part consists predominantly of sandy-clay layers interbedded with fine sands, thin volcanic ash and conglomerates (Fig. 2). Its sedimentary features appear to be similar to the upper part of the Gombore-I. Samples were collected at 15 levels (SD2EF-SD7, Fig. 2). Five sites were from a section exposed about $2 \mathrm{~m}$ in height and predominantly composed of a tuffaceous layer (SD2AeSD2EF). The remaining eight samples were from another section $8 \mathrm{~m}$ thick, dominated by sandy-tuffaceous layers, a few meters away from the first one. In each case the intervals between the different sampled horizons were separated by less than $1 \mathrm{~m}$.

\subsection{Composite stratigraphy}

A composite stratigraphy has been constructed by correlation from section to section of different marker tuffs and clay deposits with the help of fauna assemblages and prehistoric sequences. Lithostratigraphic correlation was often hampered by local erosional phases interrupting stratigraphic sequences. The paleomagnetic sampling has been synthesized in Fig. 2 with an altitude reference above the base of Garba IV clay layer.

\section{Laboratory procedures}

Because fine grained deposits yield the most accurate detrital remanent magnetization (DRM) results, claystones and tuffs were preferentially selected for analysis. All measurements were done at the CEREGE paleomagnetic laboratory installed in a magnetically shielded room with a residual field of about $1 \mathrm{mT}$. Remanent magnetizations were measured on $8 \mathrm{~cm}^{3}$ cubic specimens using a 3-axis superconducting magnetometer (2G-Enterprise, Model 760R). Alternating field (AF) demagnetizations were performed using a Schonstedt Demagnetizer and/or with the $2 \mathrm{G}$ in-line degaussing system. Thermal demagnetizations were done in a magnetically shielded Pyrox furnace and in a Magnetic Measurement Thermal Demagnetizer (MMTD) furnace. Magnetization components were analyzed using orthogonal plots (Zijderveld, 1967) and principal 
component analysis (Kirschvink, 1980). The maximum angular deviation (MAD) of the least square lines was used as a selection criterion. In general, characteristic remanent magnetization with MAD $>10$ was regarded as poorly defined and was rejected from further analysis. Directional clusters were analysed using Fisher statistics (1953).

Rock magnetic measurements were performed on AF demagnetized specimens from each studied lithological unit, in order to identify the mineralogical nature of magnetization carriers, to determine their magnetic domain state, and to evaluate the grain size ranges. These treatments include the stepwise acquisition of isothermal remanent magnetization (IRM) to saturation, the $\mathrm{AF}$ demagnetization and thermal demagnetization of saturated IRM (SIRM) and the acquisition of hard isothermal remanent magnetization (hIRM). Hysteresis loops were also studied on microsamples using a Princeton Measurement Corporation Micromag Alternating Gradient Magnetometer (mMAG) to determine the saturation induced magnetization Ms, the saturation remanent magnetization Mrs, the coercive field $\mathrm{Hc}$, and the coercivity of remanence, Hcr. Thermomagnetic analyses were performed using the CS2 high temperature unit coupled with the KLY-2 kappa bridge; the anisotropy of magnetic susceptibility (AMS) measurements was done using the KLY-2 kappa bridge following the AMS protocol of measurements.

\section{Results and discussion}

\subsection{Paleomagnetism}

The natural remanent magnetization (NRM) intensities range from $0.5 \mathrm{~mA} / \mathrm{m}$ to $73 \mathrm{~mA} / \mathrm{m}$, and low-field susceptibility varies from 0 to 280

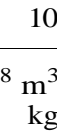

NRM directions of the 214 studied specimens are oriented in the $\mathrm{N}-\mathrm{W}$ and $\mathrm{N}-\mathrm{E}$ directions except for a few sites with SSE or intermediate directions (Fig. 3a).

In order to test stability and to determine the unblocking temperature spectra of the magnetizations, two pilot specimens from each site were subjected to a 12 step AF treatments from $2.5 \mathrm{mT}$ to $100 \mathrm{mT}$ and to 15 temperature steps levels from $50 \mathrm{C}$ to $680 \mathrm{C}$. In order to monitor possible chemical changes caused by heating in air, the magnetic susceptibility was measured after each heating steps using a Bartington susceptibility bridge. From these pilot studies, the demagnetization steps required for blanket treatment of the bulk population of specimens were determined.

Duplicate specimens from each horizon exhibit similar behavior upon $\mathrm{AF}$ and thermal stepwise demagnetization, indicating the efficiency of both method in removing the viscous remanent magnetization (VRM). The median destructive field (MDF) ranges between $10 \mathrm{mT}$ and $30 \mathrm{mT}$ with a mode at $20 \mathrm{mT}$. For normal polarity sites, the high unblocking field directions of the characteristic remanent magnetization (ChRM) were easily distinguished during AF demagnetization above peak fields of $25 \mathrm{mT}$. However, it appeared that AF demagnetization was not usually applicable for the reverse polarity sites. Therefore, thermal treatment was used systematically in the rest of the sample sets to isolate the ChRM.

Typical orthogonal plots, NRM intensity plots, and magnetic susceptibility plots of thermal demagnetizations from reversed (Fig. 4a) and normal polarity (Fig. 4b) sites are shown. The stability of the remanence and the strength of the secondary overprint varied widely between different lithological units and between different localities. In general, thermal demagnetization allowed the separation of two magnetization components. A low unblocking temperature $\left(\mathrm{T}_{\mathrm{lb}}\right)$ component overprint, usually directed along the present day geomagnetic field direction, is removed below $300 \mathrm{C}$ (Fig. 4). The contribution of this component to the total NRM is variable, but may represent more than $50 \%$ of
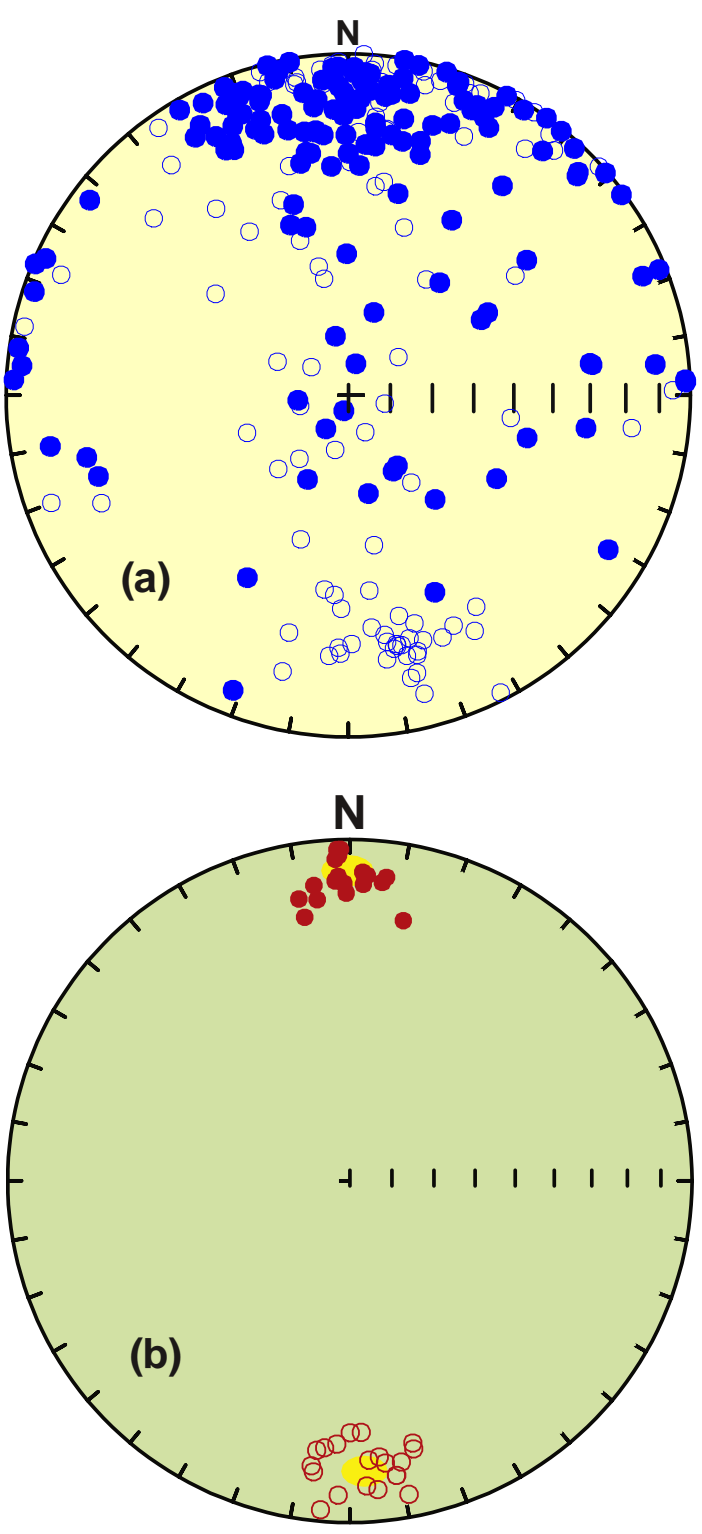

Fig. 3. Equal area projection of (a) natural remanent magnetization (NRM) and (b) sitemean characteristic remanent magnetization (ChRM) of the Melka Kunture archaeological site. Solid symbols indicate downward directions and open symbols represent upward directions of the magnetization vector. Ellipses in (b) correspond to the $a_{95}$ values of grouped normal and reversed polarity sites.

the total intensity, and is considered to be a viscous remanent magnetization (VRM). After removal of this $\mathrm{T}_{\mathrm{lb}}$, the high unblocking temperature spectrum $\left(\mathrm{T}_{\mathrm{hb}}\right)$ extends to $600 \mathrm{C}$ (Fig. 4). The directions drawn from this high temperature range formed a cluster or endpoint, and the removed magnetization (RM) obtained by line fitting within this high temperature range characterizes a higher stability magnetization of either normal (Fig. 4b) or reverse (Fig. 4a) polarity. At $600 \mathrm{C}$ the remanence intensity reached a minimum value, and then at subsequent heating up to $680 \mathrm{C}$, the increase of the residual RM intensity probably resulted from alteration of the remanence carriers. Thermally induced changes of magnetic mineralogy also occurred above w300 C, as suggested from bulk susceptibility changes (Fig. 4). Some samples show relatively stable values for temperatures up to $450 \mathrm{C}$. A susceptibility decrease generally observed above $500 \mathrm{C}$ indicates a moderate oxidation of the magnetite grains. The high $\mathrm{T}_{\mathrm{hb}}$ (between 


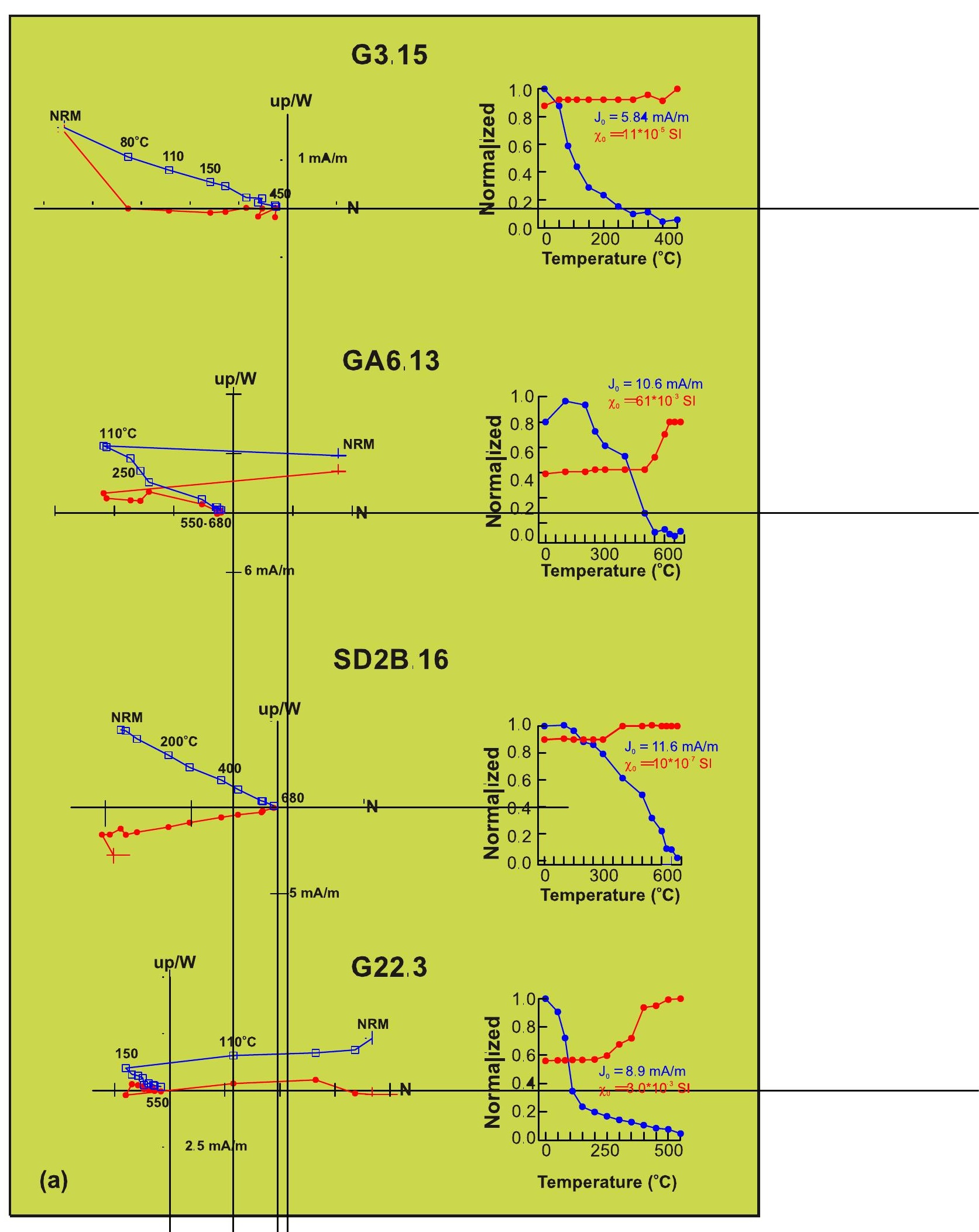

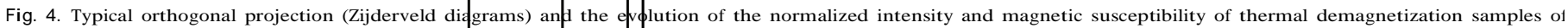

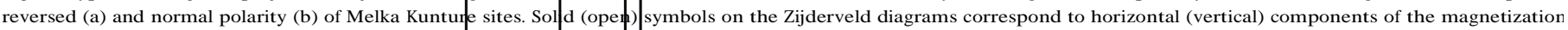
vector, respectively. 


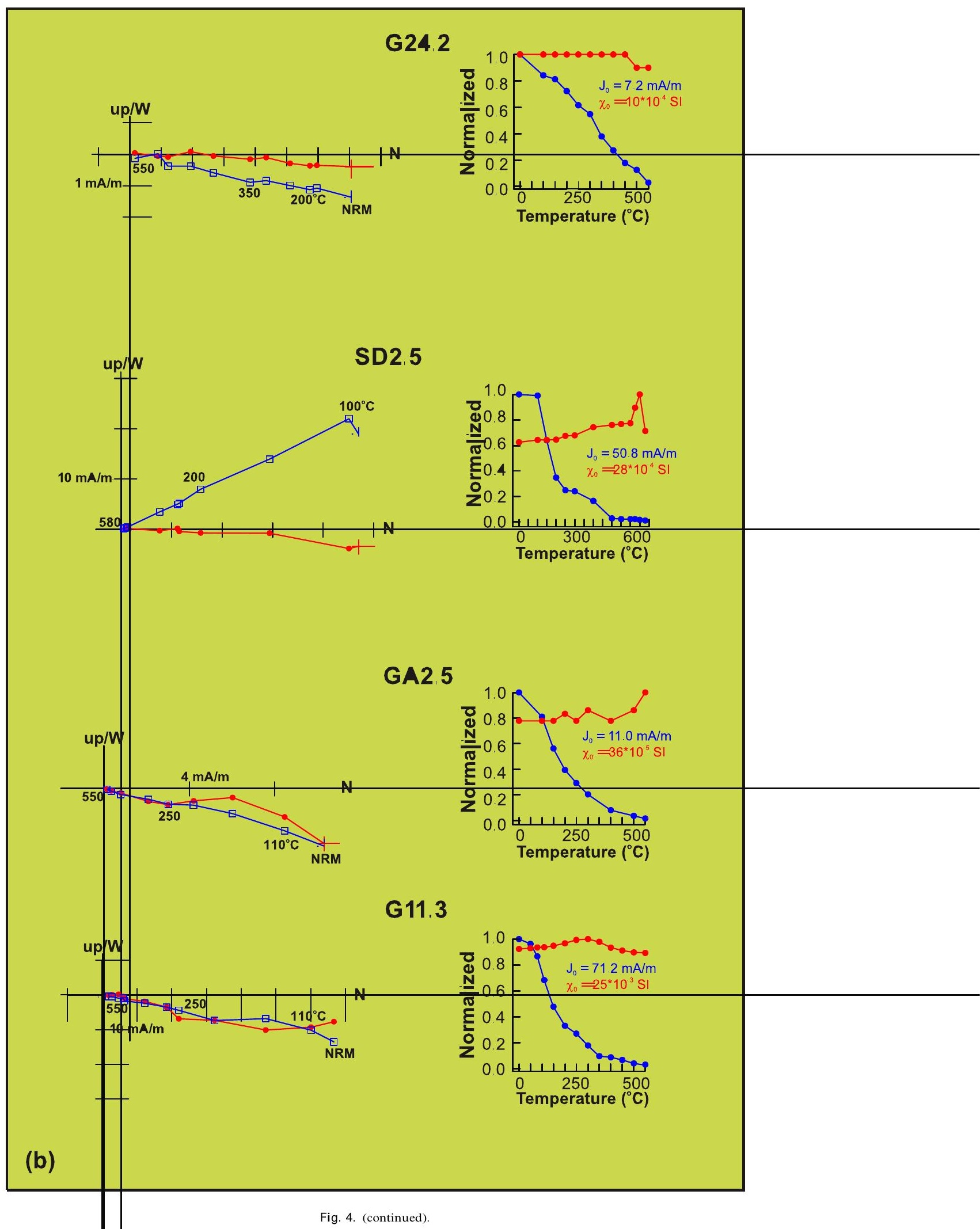

550 and $600 \mathrm{C}$ ) indicates that in nost sites the magnetic carriers are magnetite or low-Ti content nagnetite. We interpreted the directions of these $T_{h b}$ as charact ristic directions of each specimen and used these directions in the final interpretation of the magnetic polarity.

\subsection{Rock magnetism}

Results of rock magnetic experiments on selected samples (Figs. 5 and 6) helped to identify the magnetic carriers as summarized below. 

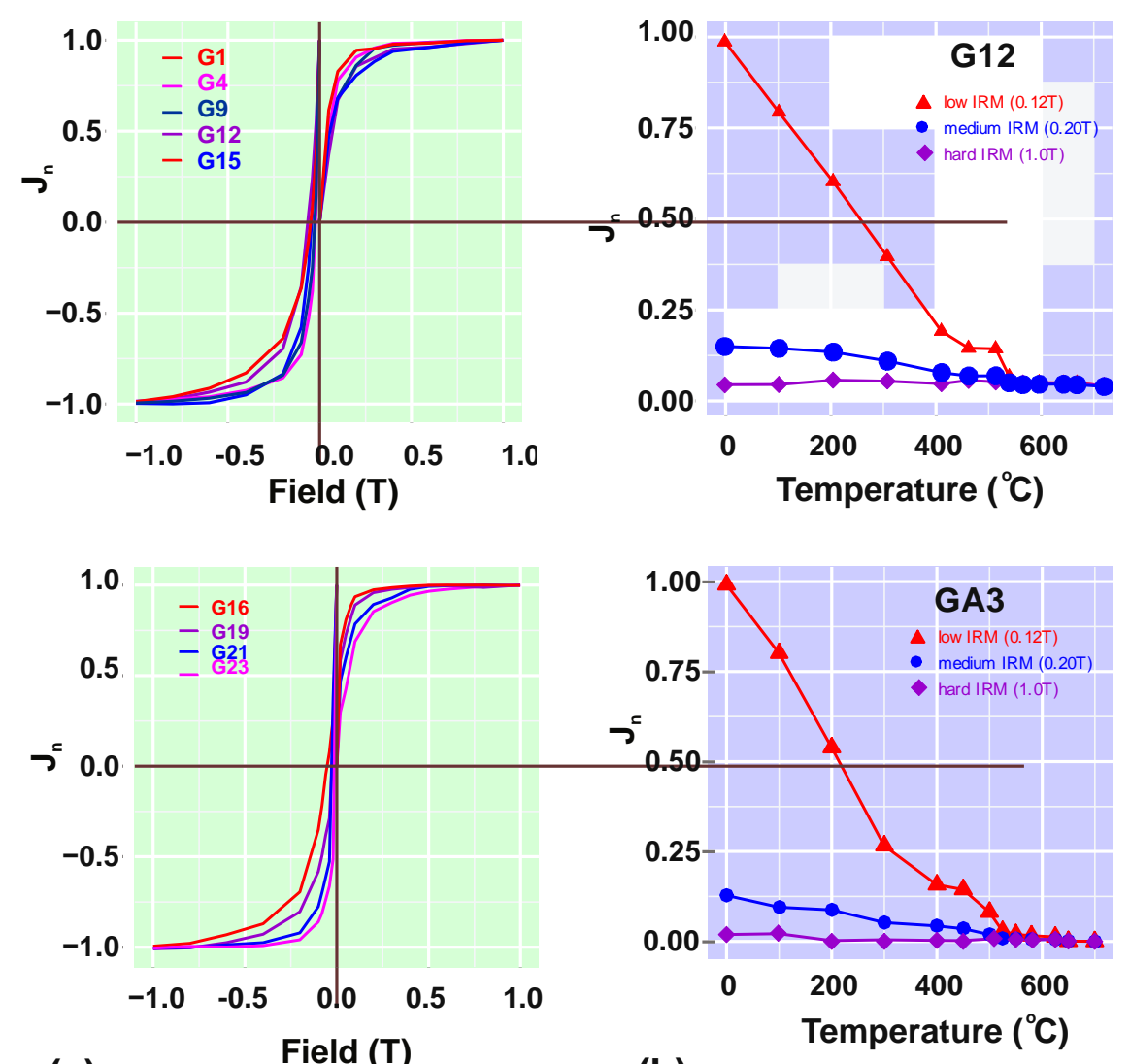

(a)

Field (T)

(b)

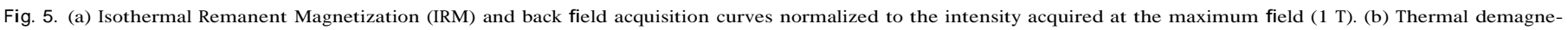

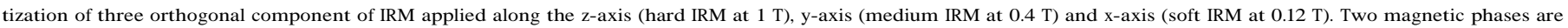
apparent on the soft IRM, a decay up to $400 \mathrm{C}$ is mainly attributed to Ti-rich magnetite and above this temperature the remaining IRM is carried by pure magnetite.

\subsubsection{IRM and S-ratio}

Stepwise acquisition of the Isothermal Remanent Magnetization (IRM) up to 1 tesla (T) was performed on samples stratigraphically distributed throughout the whole section. IRM curves are dominated by an initial steep rise at $250 e 300 \mathrm{mT}$, suggesting the presence of a low-coercivity phase magnetic mineral such as Timagnetite or Ti-maghemite. At higher field values, the IRM increases gradually up to saturation near $400 \mathrm{mT}$ (Fig. 5a). A reversed field of $0.3 \mathrm{~T}$ was applied subsequently in order to evaluate the coercivity and to compute the S-ratio (computed as $S \quad 1 / 4$

\section{IRM}

0.3T/ $\mathrm{IRM}_{1 \mathrm{~T}}$ Bloemendal et al., 1988). This ratio helps to evaluate a per-centage of the amount of magnetization component carried by the soft magnetic fraction. More than 95\% of S-ratio values are between 0.9 and 0.98 , and supporting the dominance of a low coercivity fraction. Hcr proxy-values computed from back-field IRM acquisi-tion vary between 15 and $30 \mathrm{mT}$ with a rather sharp mode in the range $20 \mathrm{e} 25 \mathrm{mT}$ (Fig. 5a).

\subsubsection{Thermal demagnetization of orthogonal IRM}

In order to precisely determine the nature of the magnetic components, selected samples were given an isothermal remanent magnetization (IRM) in three orthogonal direction at various field values (1.0 T, $0.4 \mathrm{~T}$ and $0.12 \mathrm{~T}$ ) and then thermally demagnetized using the Lowrie (1990) technique. The thermal decay of the IRM concerns the $0.12 \mathrm{~T}$ (i.e. soft IRM) (Fig. 5b) which is carried by two magnetic phases of $\mathbf{w} 400 \mathrm{C}$ and $\mathbf{w} 600 \mathrm{C}$. The maximum loss of IRM (80\%) occurs below $400 \mathrm{C}$ and can be attributed either to maghemite or Ti-rich magnetite. However, the inversion of the highly magnetic mineral maghemite to the much less magnetic mineral hematite can start at about $300 \mathrm{C}$ (Stacey and Banerjee. 1974), which is not evident on hard IRM of the bulk samples (Fig. 5a). In addition, the remaining soft IRM decays almost linearly above $400 \mathrm{C}$. Maximum blocking temperatures attained between $575 \mathrm{C}$ and $600 \mathrm{C}$, clearly indicate a contribution of magnetite. This supports the large dominance and presence of magnetite, with a low contribution from high coercivity and high unblocking temperature minerals, such as hematite.

\subsubsection{Hysteresis loops}

Values of saturation magnetization (Ms), saturation remanence (Mrs) and coercive force $(\mathrm{Hc})$ were determined from hysteresis loops measured on small samples (mass about $20 \mathrm{mg}$ ). Remanence coercivity (Hcr) and Mrs were also determined from back field SIRM acquisition curves. Two representative hysteresis loops are shown in Fig. 6a (the clear paramagnetic contribution to high field susceptibility was substracted from hysteresis curves). As with bulk SIRM analyses, the saturation is achieved between 200 and $300 \mathrm{mT}$ (Fig. 6a). The ratios $\mathrm{Hcr} / \mathrm{Hc}$ range between 2.1 and 3.9 and Mrs/Ms of 0.07 e 0.22 shows a pseudo-single domain (PSD) grain size according to the Day et al. (1977) criteria.

\subsubsection{Thermomagnetic measurements}

Magnetic susceptibility changes during heating between room temperature and the curie temperature of magnetite $(580 \mathrm{C})$ or hematites $(680$ C) may characterize the chemical composition and/or the grain size distribution of the magnetic mineral contained in a sample. About $20 \mathrm{mg}$ of each powder sample were inserted into a quartz tube and heated in the CS- 2 thermomagnetic 

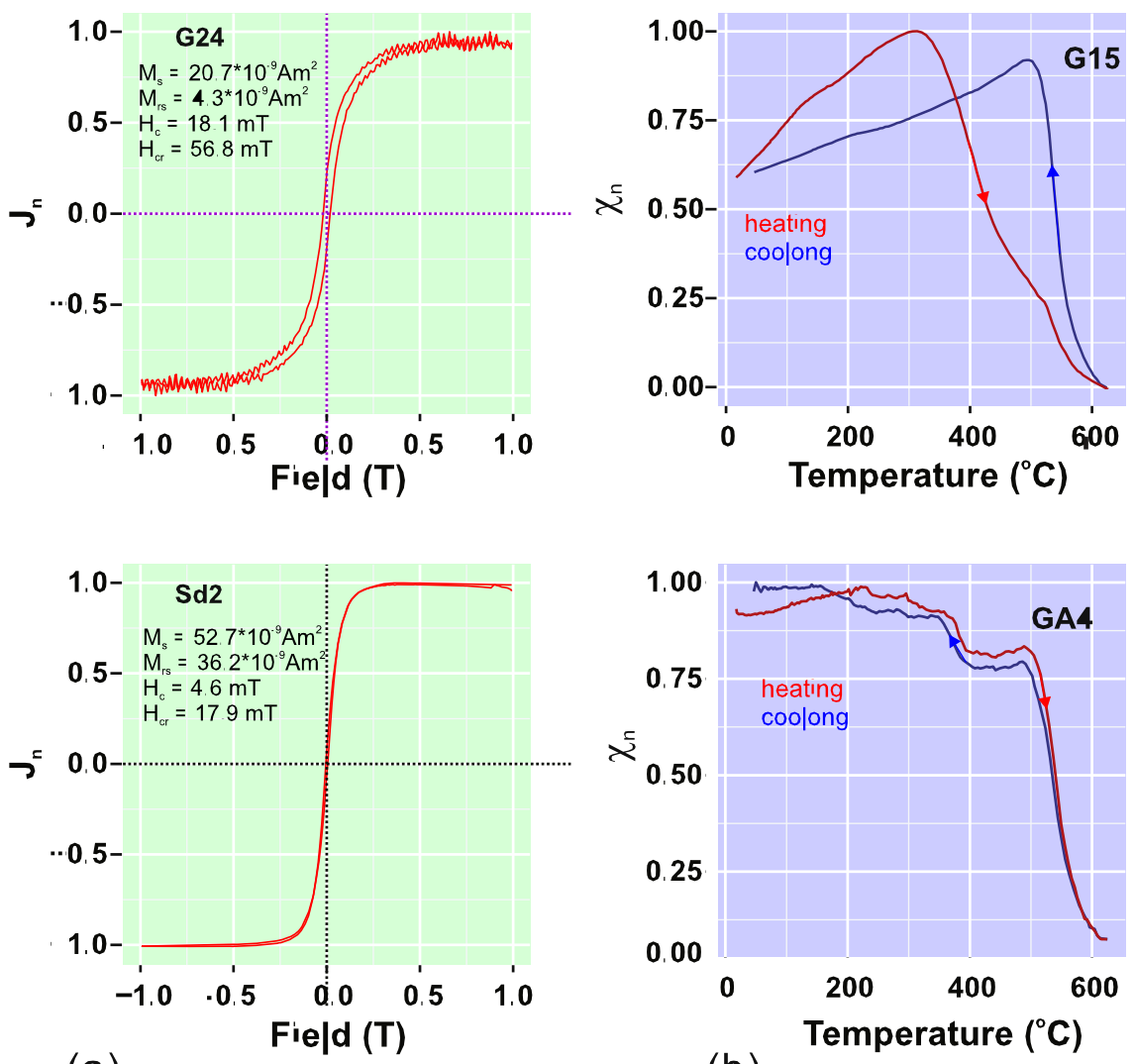

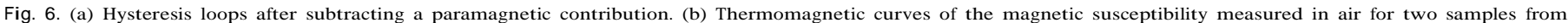
Gombore-I and Garba-IV units.

unit connected with the KLY-2 Kappa bridge. Two representative curves are presented in Fig. 6b. The first sample G15F.1, characterized by a significant amount of high coercivity magnetic minerals, shows a decrease of its initial susceptibility above $400 \mathrm{C}$. Its Curie temperature lies between $600 \mathrm{C}$ and $620 \mathrm{C}$. An irreversible increase in magnetic susceptibility (about $25 \%$ of the room temperature value) occurs during cooling, probably caused by magnetite synthesis. The second sample, GA4.4 (Fig. 6b), characterized by low coercivity magnetic minerals, represents the majority of the study samples and has a Curie temperature close to $600 \mathrm{C}$. On subsequent heating and cooling, the thermomagnetic curve is reversible and suggests a fine grained magnetite contribution to the magnetic susceptibility.

These rock-magnetic analyses suggest that in most studied sediment facies the bulk remanence is carried by a ferrimagnetic mineral such as magnetite or Ti-magnetite. Significant contributions of haematite or goethite would lead to much higher Hcr values than observed. According to the relations of $\mathrm{Hcr} / \mathrm{Hc}$ versus $\mathrm{Mr} / \mathrm{Ms}$, the grains of (Ti-) magnetite are in the stable single domain (SSD) or pseudosingle domain (PSD) state.
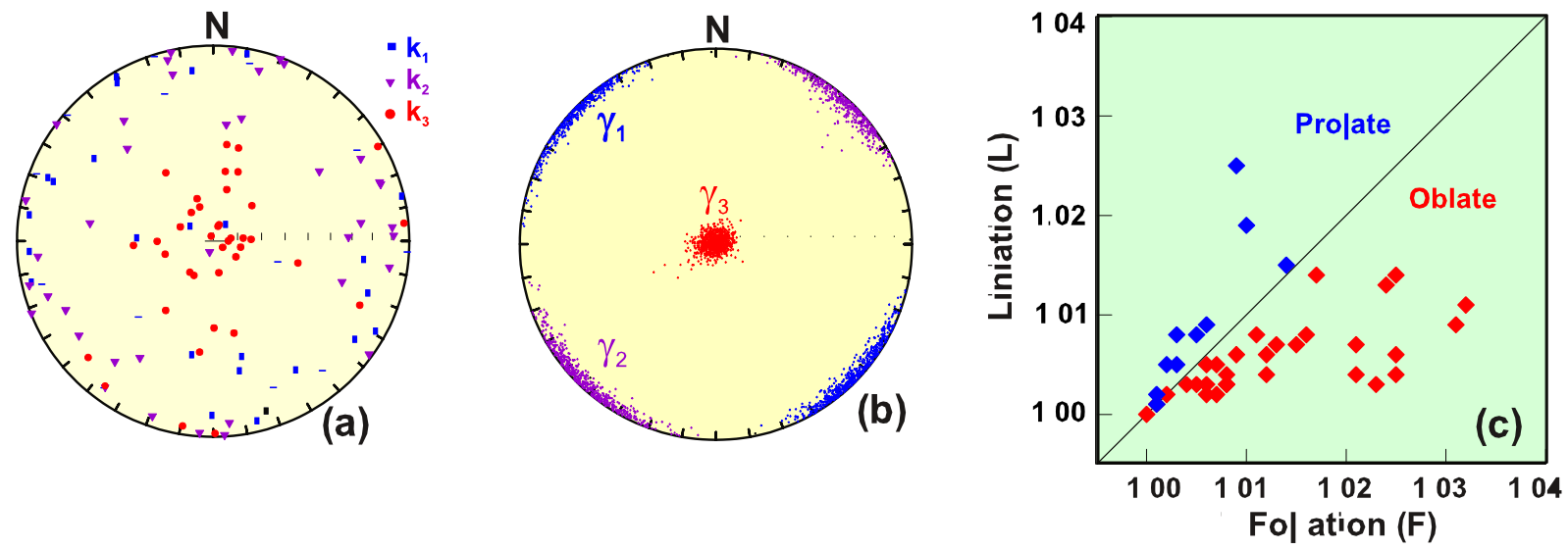

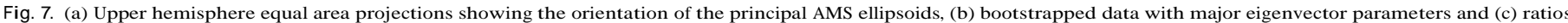

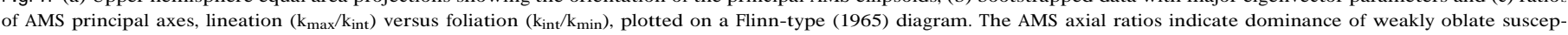
tibility ellipsoid fabrics with minimum axes perpendicular to bedding. 


\subsection{Anisotropy of magnetic susceptibility}

Low field Anisotropy of magnetic susceptibility (AMS) measurement data were performed because they yield highly significant information on the strain history of weakly magnetized undeformed sediments. AMS was measured along 15 directions of the cube sample and data were analysed using the tensorial statistics of Jelinek (1978). Mean AMS directions and associated uncertainties were determined using the bootstrapping technique of Tauxe et al. (1998) (Fig. 7b). The magnetic fabric is described by an ellipsoid in which the maximum, intermediate and minimum axes are represented by $\mathrm{k}_{\max }, \mathrm{k}_{\mathrm{int}}$ and $\mathrm{k}_{\min }$, respectively. The corrected anisotropy degree $\left(\mathrm{P}^{0}\right)$ (Jelinek, 1981), the foliation $(\mathrm{F})$ and

the lineation (L) parameters helped determine the shape parameters of the magnetic susceptibility ellipsoid (Hrouda, 1982).

We resolved the magnetic fabrics in 41 samples and obtained usable results from $80 \%$ of the sites (Fig. 7a). In these sites very high values of magnetic susceptibility (53.2

\section{$-10$}

clustered of the minimum axes almost around the ${ }_{5}$ Seftigas 8 observed (Fig. $7 \mathrm{~b}$ ). The remaining $20 \%$ of the sites have low values of magnetic susceptibility (between 1010

${ }_{5} \mathrm{SI}$ ), an increase in $\mathrm{L}$ and $\mathrm{P}^{0}$ parameters (about 1.025 and 1.061 5 SI tara values in magnetic susceptibility indicate that the main magnetic contribution is due to a combination of viscous multi-domain (MD) or super-paramagnetic (SP) components and as well as paramagnetic fractions were influencing the magnetic fabric (Tarling and Hrouda, 1993). The magnetic fabric of the measured sites is shown in Fig. 7c as lineation versus foliation (Flinn diagram, 1965). which ranges from oblate ellipsoid of pure sedimentary origin ( $\mathrm{K}_{\max } 1 / 4 \mathrm{~K}_{\text {int }}$ with $\mathrm{K}_{\min }$ perpendicular to the bedding) to prolate ellipsoid related to deformation ( $\mathrm{K}_{\max }$ parallel to the fold axes and $K_{\min } 1 / 4 K_{\text {int }}$ ) that might be related with tectonic strains that led to the observed minor faults in the upper part of the Gombore-I unit (Taieb, 1974). For the majority of the sites the magnetic fabric is oblate and the eigenvector of the maximum susceptibility ellipsoid $\left(g_{1}\right.$, Fig. $\left.7 b\right)$ shows a lineation parallel to the drainage patterns of the Awash river (NWeSE) and thus indicates a sedimentary origin of the magnetic remanence.

\subsection{Magnetostratigraphy}

The majority of the pilot specimens yielded a stable component of magnetization, represented by a linear segment toward the origin in orthogonal plots (Fig. 4a and b). Principal component analysis (PCA) (Kirschvink, 1980) allowed fitting lines through at

$\left.{ }_{5} \mathrm{SI}\right)$ and a low degree of anisotropy $\left(1.0027<\mathrm{P}^{0}<1.004\right)$. These

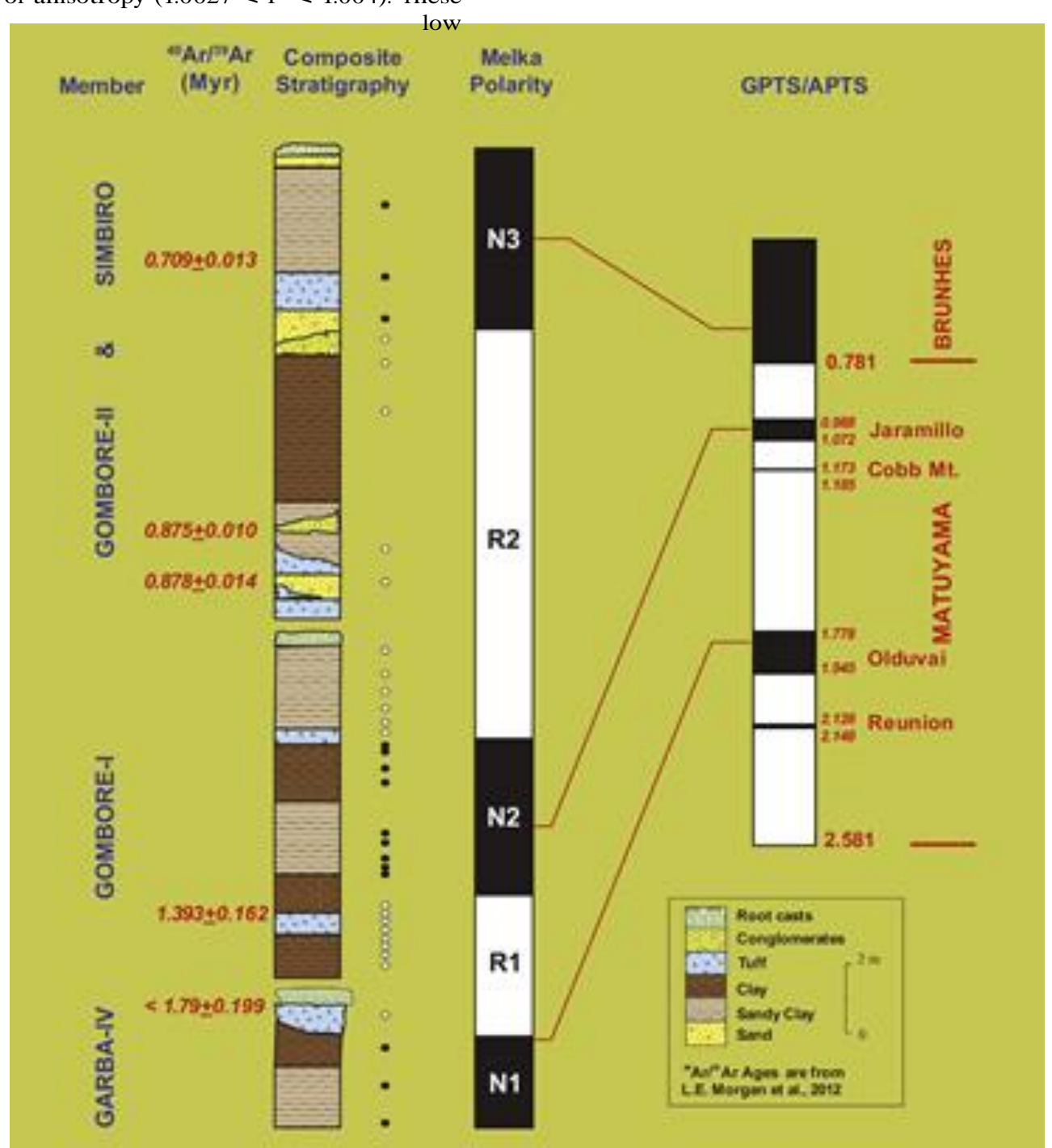

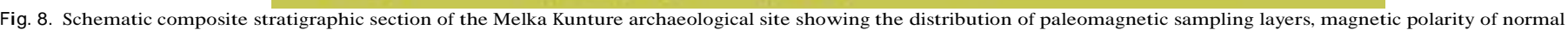
(filled circles) and reversed (open circles) polarity, and correlation with the geomagnetic polarity time scale (GPTS). 
least three points, usually directed towards the origin. For five sites, the final stage of demagnetization could not be observed and hence PCA could not be used, either because the specimens underwent chemical changes that produces new magnetic minerals at temperatures as low as $500 \mathrm{C}$, or because the magnetization intensity or direction slightly changed during thermal demagnetization. In these cases, the mean characteristic remanent magnetization (ChRM) was thus calculated using Fisher's (1953) statistics. Out of the 214 specimens studied from 42 sampling horizons, 47 specimens were rejected due to line fitting errors (MAD) $>20$, low internal precision $\mathrm{k}<8$ and $\mathrm{a}_{95}>15$ calculated from a minimum of 3 consecutive demagnetization points by using the principal component analysis.

From the bulk population ChRM vectors, the site mean direction of declination, inclination and precision parameters were computed for each sampled horizons (site) and for groups of normal and reversed polarity sites. For 28 out of 44 sites, the statistical parameters are fully satisfying, and within site directions were usually well grouped (typically $a_{95}<15$ and $15.2<\mathrm{k}<221.8$ ), while for 6 additional sites the $a_{95}$ values range between 16.1 and 25.6 with $\mathrm{k}>9$. A further 7 sites represented only by two specimens, from each site, were included in our mean calculation due to their consistency in the magnetization direction However, one site (GA5) had a mean direction departed significantly from the expected geocentric axial dipole field (GAD) direction of the MK locality (Dec $1 / 40$ and Inc $1 / 414$ ) by more than 30, and two sites of the lower part of Gombore-II section (G18 and

G19, Fig. 2) with inconsistent magnetization direction were excluded from the magnetostratigraphic interpretation.

The grouped mean of 20 normal polarity sites gave D $1 / 4359.5$, I $1 / 49.9$ with $\mathrm{a}_{95} 1 / 44.8$ and $\mathrm{k} 1 / 4$ 46.3; and the mean of 21 reverse polarity sites gave D $1 / 4 \quad 177.3$, I $1 / 4$

16.2 with $a_{95} 1 / 4 \quad 4.1$ and $\mathrm{k}^{1 / 4} 61.3$ and defines two antipodal clusters (Fig. 4b). The combined mean of both normal and reverse polarity of 41 sites were D $1 / 4$ 358.4, I $1 / 4$ 13.1, $a_{95} 1 / 43.2$ and $k 1 / 449.9$.

The overall paleomagnetic data of the Melka Kunture sequence show the presence of two reversed and three normal magnetozones (N1, R1, N2, R2, and N3) (Fig. 8). The magnetozone boundaries are placed midway between two adjacent sampling levels (site) of opposite polarity. Excepting the polarity interval R1 of the Garba-IV section represented by only one site, all magnetozones are 4.5ined by three to six sampling levels.

Before establishing correlation with the geomagnetic polarity times scale, it is necessary to review the geochronological information available for the Melka Kunture site. The sedimentary sequence is believed to have been deposited since $2 \mathrm{Ma}$, according to a previously established geochronological framework determined from conventional radiometric dating $\left(\mathrm{K} / \mathrm{Ar},{ }^{40} \mathrm{Ar} /{ }^{39} \mathrm{Ar}\right.$ ), biostratigraphic correlations, cultural contents and preliminary paleomagnetic studies. The various approaches applied to a time frame for this sequence are summarized and discussed below using newly obtained radiometric ages and paleomagnetic results of other similar sedimentary deposits in the region.

\subsubsection{KeAr dates}

Schmitt et al. (1977) dated some samples from the lower part of the Melka Kunture locality to determine numerical radiometric ages using the conventional KeAr methods. The KeAr ages were determined on the marker tuffs A, C, and of the welded tuff (tuff D) taken from the upper top level of the Gombore-II section. KeAr ages gave a maximum age of $1.53 \mathrm{Ma}$ for Tuff $\mathrm{A}$ and a minimum age of $0.72 \mathrm{Ma}$ for Tuff D (Schmitt et al., 1977). In spite of their dispersion, these ages were used as a basis for biostratigraphic and paleomagnetic correlations in former studies of the Melka Kunture localities and were used to infer ages for the various archaeological findings.

\subsection{2. ${ }^{40} \mathrm{Ar} /{ }^{39} \mathrm{Ar}$ dates}

Morgan et al. (2012) have studied the various tuffaceous units of the Melka Kunture localities using ${ }^{40} \mathrm{Ar} /{ }^{39} \mathrm{Ar}$ radiometric methods. An older age of $>1.790 .199$ Ma was reported for the tuffaceous unit located at the base of Garba-IV. A reliable age constraints of $1.3930 .162 \mathrm{Ma}$ was reported from the base of Gombore-I section Ages of 0.8750 .010 and $0.7090 .013 \mathrm{Ma}$ from Gombore-II site

and $0.8780 .14 \mathrm{Ma}$ from Simbiro were also reported. Some of the new ${ }^{40} \mathrm{Ar} /{ }^{39} \mathrm{Ar}$ ages of Morgan et al. (2012) are shown in Figs. 2 and 8 along with the sections studied in the present paper.

\subsubsection{Biostratigraphy and archaeology}

According to Chavaillon $(1971,1973,1979)$ and Geraads (1979, 1985), the cultural levels identified at Melka Kunture vary from Oldowan to Acheulian dated from early to middle Pleistocene. The large mammal assemblage of this sequence is mainly composed of bovids dominated by Alcelaphini and Antilopini, Reduncini and absence of Tragelaphini, followed by suids, equids, hippopotamids and giraffids, indicative of semi-arid and open-savanah environments, consistent with palynological data (Bonnefille, 1976). The faunal composition is very similar to the Olduvai Formation (Tanzania) and Turkana (Kenya) fossil associations and shows a similar pattern of specific or sub-specific distinction from contemporary forms (Geraads et al., 2004). The occurrence of Pelorovis turkanensis brachyceras at Simbiro III and the presence of an archaic form of Kolpochoerus in Garba could correlate with Bed IIIeIV of the Olduvai Formation although geographical and ecological variation probably occurred related to the highland location of Melka Kunture (Geraads et al., 2004). The sequence at Melka Kunture corresponds to the sequence of the Olduvai Formation, and sections Gombore I, Garba IV and Simbiro are probably contemporaneous to upper members of the Omo (Ethiopia) and East Turkana (Kenya) formations.

Extensive excavation at the Garba-IV and Gombore-I sections indicates an extensive occupation site with an Oldowan industry correlated to the well-documented faunal assemblage of the lower and middle Bed I of the Olduvai Formation (Chavaillon and Koeniguer, 1970; Chavaillon, 1979). Ages inferred using ${ }^{40} \mathrm{Ar} /{ }^{39} \mathrm{Ar}$ isotopic dating for the lower and middle part of Bed I (Tuff IB and Tuff IF) of the Olduvai Formation span from 1.85 Ma. to 1.75 Ma (Walter and Aronson, 1993). Paleomagnetic samples studied from Bed I of the Olduvai Formation showed a thick normal polarity interval and correlation with the Olduvai subchron (Tamrat et al., 1995). Therefore, biostratigraphic correlation of the base of Garba-IV and Gombore-I sections indicates an estimated age of about $1.75 e 1.80 \mathrm{Ma}$.

A sequence of five archaeological levels of Garba IV was compared with the evolved Oldowan assemblages of the Olduvai Bed II (Piperno and Piperno, 1975; Chavaillon et al., 1978). Paleomagnetically dated horizons of Bed II at Olduvai showed a reversed polarity of the Matuyama chron, corresponding to the end of the Olduvai subchron (Tamrat et al., 1995). The suggested age of the Garba-IV unit is not more than $1.75 \mathrm{Ma}$. In addition, a rich assemblage of fossil faunas documented from the Simbiro locality are well comparable to the lower (early) Acheulian industry (Chavaillon, 1971). Regional correlation indicates an age comparable with Bed III of the reversed polarity of the Olduvai Formation, dated using paleomagnetism between the Cobb Mountain normal polarity event and the Jaramillo subchron, at about 1.1 Ma (Tamrat et al., 1995). 
The Gombore-II section in which both middle and more evolved Acheulian assemblage and some specimens of human remains, notably a fragment of left parietal assigned to Homo erectus, is correlated to the Bed IV of the Olduvai Formation (Chavaillon and Piperno, 1975; Brahimi, 1976; Chavaillon et al., 1978). Tamrat et al. (1995) have placed Bed IV of the Olduvai Formation within the reversed Matuyama chron, which preceded the Brunhese Matuyama transition, at about $0.8 \mathrm{Ma}$. Therefore, biostratigraphic correlation of the various localities of the Melka Kunture archaeological site sets a maximum and minimum age of about $1.8 \mathrm{Ma}$ and $0.7 \mathrm{Ma}$, respectively.

\subsubsection{Previous paleomagnetic study}

Initial paleomagnetic studies of the Melka Kunture site were reported by Westphal et al. (1979) and Cressier (1980). These study was carried out on samples collected from the four sections mentioned above. According to this preliminary paleomagnetic study, two transitions from reversed to normal polarity were identified at Melka Kunture. The first reversal occurred above Tuff A in the upper part of the Gombore-I section and a second reversal occurred between Tuffs C and D within the Gombore-II section. Correlation to the geomagnetic polarity time scale (GPTS) was based on the radiometric ages (KeAr) and biostratigraphic correlations mentioned above. Overall, these preliminary paleomagnetic result indicates that the uppermost part of the Gombore-II section has an age of 0.73 Ma (Cressier, 1980).

\section{Correlation to the GPTS}

Magnetostratigraphic polarity patterns of the composite Melka Kunture locality sections correlate with the 'Astronomically Tuned Neogene Time Scale (ATNTS2004)' of Lourens et al. (2004) and with the recent published GPTS of Gradstein et al. (2012). For correlation purposes, we used several tie points discussed in the previous sections. These include: (i) ${ }^{40} \mathrm{Ar} /{ }^{39} \mathrm{Ar}$ ages older than $0.7 \mathrm{Ma}$ and younger than $1.80 \mathrm{Ma}$. (ii) most archaeological artefacts correlated with various levels of other well dated sequences of the East African archaeological and hominid sites (e.g. Olduvai Formation of the upper part of Bed I and Bed II, Chavaillon, 1971), which have both ${ }^{40} \mathrm{Ar} /{ }^{39} \mathrm{Ar}$ dating (Walter et al., 1991) and magnetostratigraphy (Tamrat et al., 1995)

We thus propose a direct correlation of the Melka Kunture composite magnetostratigraphic section with the GPTS. We interpret the normal polarity interval (N1) as the end of the Olduvai subchron, and the reversed polarity interval (R1) as the postOlduvai Matuyama reversed polarity. The normal and reversed polarity zones above R1 are correlated to the Jaramillo sub-chron $(\mathrm{N} 2)$, and the Brunhes chron (N3). The reversed polarity zone (R2) represents the end of the Matuyam chron (Fig. 8). Accordingly, the Melka Kunture localities are confirmed to be deposited between ca $1.80 \mathrm{Ma}$ and $0.70 \mathrm{Ma}$.

\section{Conclusion}

Based on detailed paleomagnetic, rock magnetic and AMS data, we have established the magnetostratigraphic record of the Melka Kunture sequences from four sections of Gombore-I, Gombore-II, Garba-IV and Simbiro. The various rock magnetic results indicate that the dominant magnetic mineral is a (Ti-)magnetite, lying in the pseudo-single domain grain-size range. The presence of a high coercivity fraction haematite or goethite is suggested by thermomagnetic analysis. The anisotropy of magnetic susceptibility result supports the sedimentary origin of the magnetic remanence and the lack of overprint by non-viscous secondary magnetization, as well as the grouping around two antipodal directions strongly suggest that the magnetization of the Melka Kunture sequence is a post-depositional remanent magnetization (pDRM). Although further measurements and statistics would be required to confirm the relationship between tectonic strain and the prolate fabric in some samples of the Gombore-I unit, the lineation parallel to the direction of drainage of the (paleo-) Awash river is an interesting and promising finding for further reconstructing drainage directions and depositional environments across archeological sites of East Africa.

Five magnetozones, R1eN3, are correlated with the late Matuyama chron (from late Olduvai to post-Jaramillo) and with the Brunhes chrons. The localities are bracketed between early and upper Pleistocene. The reconstructed paleomagnetic polarities show a robust magnetostratigraphical framework which is consistent with radiometric $\mathrm{K} / \mathrm{Ar}$ and $\mathrm{Ar} / \mathrm{Ar}$ ages. These correlations provide several firm chronological determinations which can be used to calculate relative ages for the various faunal and artifact records at the Melka Kunture archaeological site and similar fossiliferous deposits in the region. The results presented in this study improve the earlier magnetostratigraphy and chronostratigraphy of Melka Kunture, a key issue to improve the understanding of Pleistocene archeological environments in East Africa. As stressed, for example by the absence of the Cobb Mountain event. further studies could use this framework to better assess the timing of the major deposition hiatus in Melka Kunture, and explore their consistency with existing regional syntheses of Pleistocene depositional change in East Africa.

\section{Acknowledgments}

We would like to extend our special thanks to the Authority for Research and Conservation of the Cultural Heritage of Ethiopia (ARCCH), the Ministry of Culture and Tourism of Ethiopia, the Oromia Culture and Tourism Bureau, for providing permissions, guidance and administration support for the field work. We thank K. Gemechu, D. Asamerew, A. Hurgesa and G. Gashu for their help in the field. This paper was improved as a result of constructive review comments from David Williamson, Norm Catto, David Pleurdeau and two anonymous reviewers. This work was financially supported by the French Ministry of Foreign Affairs to TE and CEREGE funding to NT. The paper is dedicated to Dr. Mohammed Umer and Solomon Teshome.

Bailloud, G., 1965. Les gisement paléolitiques de Melka Kunturé (Choa). Cahier n 1 Instiute éthiopien d'Archéologie, Addis-Ababa, Ethiopia.

Bloemendal, J., Lamb, B., King, J., 1988. Paleoenvironmental implications of rockmagnetic properties of late Quaternary sediment cores from the eastern equatorial Atlantic. Paleoceanography 3, 61 e87.

Bonnefille, R., 1972. Association polliniques actuelles et quaternaires en Ethiopie (Vallées de l'Awash et de l'Omo) (Thèse de doctorat es Sciences). Université Paris, France, p. 511

Bonnefille, R., 1976. Végétations et climats des temps oldowayens et acheuléens à Melka Kunturé (Ethiopie). In: L'Ethiopie avant l'histoire, vol. 1CNRS, pp. 55e71.

Brahimi, C., 1976. Rapport de fouilles du site de Gomboré II, Acheuléen moyen. In: L'Ethiopie avant l'Histoire, vol. 1CNRS, pp. 39 e 44.

Chavaillon, J., 1967. La Préhistoire éthiopienne à Melka Kunturé. Archéologia 19, $56 e 63$.

Chavaillon, J., 1971. Les habitats préhistoriques en Ethiopie: Melka Kunturé. Sciences $73,44 \mathrm{e} 52$

Chavaillon, J., 1973. Chronologie des niveaux paléolitique de Melka Kunturé. Comptes Rendus Académie des Sciences, Paris 276, 1533 e1536. 
Chavaillon, J., 1979. From the Oldowan to the Middle Stone Age at Melka Kunturé (Ethiopia). Understanding cultural changes. Quaternaria 21, 87e113.

Chavaillon, J., Berthelet, A., 2004. The archaeological sites of Melka Kunture. In Chavaillon, J., Piperno, M. (Eds.), Studies on the Early Paleolithic Site of Melka Kunture, Ethiopia. Origines. Instituto Italiano di Preistoria e Protostoria, Firenze pp. $25 e 80$.

Chavaillon, J., Koeniguer, J.C., 1970. Découverte d'un fragment de liane dans le sol oldowayen de Melka Kunturé. Comptes Rendus Académie des Sciences, Paris 270, 1969e1972.

Chavaillon, J., Piperno, M., 1975. Garba IV, site paléolithique ancien de Melka Kunturé. Bulletin Société Préhistorique francaise 72, 134e138

Chavaillon, J., Taieb, M., 1968. Stratigraphie du Quaternaire de Melka Kunturé, Valée de l'Awash, Ethiopie. Premiers résultats. Comptes Rendus Académie des Sciences, Paris 266, 1210e1212.

Chavaillon, J., Chavaillon, N., Hours, F., Piperno, M., 1978. Le début et la fin de l'acheuléen à Melka Kunturé: méthodologie pour l'étude des changements de civilisations. Bulletin Société Préhistorique francaise 75, $105 e 115$.

Cressier, P., 1980. Magnétostratigraphie du gisement pléistocène de Melka Kunturé (Thèse de 3 cycle). Institut Physique de Globe, Strasbourg, France, p. 167

Day, R., Fuller, M., Schmidt, V.A., 1977. Hysteresis properties of titanomagnetites: grain size and compositional dependence. Earth and Planetary Interiors 13, $260 e 267$.

Deino, A., Potts, R., 1990. Single crystal ${ }^{40} \mathrm{Ar} /{ }^{39} \mathrm{Ar}$ dating of the Olorgesaille Formation, southern Kenya Rift. Journal of Geophysical Research 95, 8453e8470.

Dekker, G., 1964. Une découverte: le gisement de Melka Konturé. New Scientist 384

Fisher, R.A., 1953. Dispersion on a sphere. Proceedings of the Royal Society A 217 , 295 e305.

Flinn, D., 1965. On the symmetry principle and the deformation ellipsoid. Geological Magazine 102, 36e 42

Fuller, M., Goree, W.S., Goodman, W.L., 1985. An introduction to the use of SQUID magnetometers in biomagnetism. In: Kirschvink, J.L. (Ed.), Magnetite, Biomeneralization and Magnetoreception in Organisms. Plenum, New York pp. $103 e 151$

Geraads, D., 1979. La faune des gisments de Melka Kunturé (Ethiopie): Artiodactyles, Primates. Abbay Etudes Ethiopiennes 10, 21 e49.

Geraads, D., 1985. La faune des gisements de Mekla Kunturé. In: L'environnemen des Hominidés au Plio-Pléistcoène. Fondation Singer Polignac, Paris, Masson pp. $165 \mathrm{e} 174$

Geraads, D., Eisenmann, V., Petter, G., 2004. The large mammals fauna of the Oldowan sites of Melka Kunturé. In: Chavaillon, J., Piperno, M. (Eds.), Studies on the Early Paleolithic Site of Melka Kunture, Ethiopia. Origines. Instituto Italiano di Preistoria e Protostoria, Firenze, pp. 169e192.

Gradstein, F.M., Ogg, J.G., Schmitz, M.D., Ogg, G.M., 2012. The Geologic Time Scale 2012. Elsevier, p. 1144, 2 volumes.

Hours, F., 1971. Le Middle Stone Age de Melka Kunturé. In: Berhanu, A. Chavaillon, J., Sutton, R. (Eds.), Actes du VII Congrés Panafrican de Préhistoire el Etudes du Quaternaires, pp. 99e104. Addis Ababa, Ethiopia.

Hrouda, F., 1982. Magnetic anisotropy of rocks and its application in geology and geophysics. Geophysical Survey 5, 37e82.

Jelinek, V., 1978. Statistical processing of anisotropy of magnetic susceptibility measured on group of specimens and its applications. Studia Geophysica \& Geodetica 22, 50 e62.

Jelinek, V., 1981. Characterization of the magnetic fabric of rocks. Tectonophysics 79, $63 e 67$.
Kirschvink, J.L., 1980. The least squares line and plane and the analysis of paleomagnetic data. Journal of the Royal Astronomical Society 62, 699e 718.

Lo Bello, P., Féraud, G., Hall, C.M., York, D., Lavina, P., Bernat, M., 1987. ${ }^{40} \mathrm{Ar} /{ }^{39} \mathrm{Ar}$ stepheating and laser fusion dating of a Quaternary pumice from Neschers, Massi Central, France: the defeat of xenocrystic contamination. Chemical Geology 66 $61 \mathrm{e} 71$.

Lourens, L., Hilgen, F., Shackleton, N.J., Laskar, J., Wilson, D., 2004. The Neogene period. In: Gradstein, F., Ogg, J., Smith, A.G. (Eds.), A Geologic Time Scale. Cambridge University Press, pp. 409e440.

Lowrie, W., 1990. Identification of ferrimagnetic minerals in a rock by coercivity and unblocking temperature properties. Geophysical Research Letters 17, $159 e 162$.

Morgan, L.E., Renne, P.R., Kieffer, G., Piperno, M., Gallotti, R., Raynal, J.P., 2012 A chronological framework for a long and persistent archaeological record: Melka Kunture, Ethiopia. Journal of Human Evolution 62, 104e115.

Piperno, M., Piperno, B.G.M., 1975. First approach to the ecological and cultural significance of the early paleolithic occupation site of Garba IV at Melka Kunturé (Ethiopia). Quaternaria 18, 347 e382.

Renne, P.R., Walter, R., Verosub, K., Sweitzer, M., Aronson, J., 1993. New data from Hadar (Ethiopia) support orbitally tuned time scale to $3.3 \mathrm{Ma}$. Geophysical Research Letters 20, 1067e1070.

Schmitt, T.J., Wempler, J.M., Chavaillon, J., Andrews, M.C.J., 1977. Initial K/Ar and paleomagnetic results of the Melka Kunture early man sites, Ethiopia. In: VII PanAfrican Congress of Prehistory and Quaternary Studies, Nairobi

Stacey, F.D., Banerjee, S.K., 1974. The Physical Principles of Rock Magnetism. Elsevier Amsterdam, p. 195

Taieb, M., 1974. Evolution quaternaire du bassin de l'Awash (Thése de Doctorat ès Sciences). Université de Paris, France, p. 390

Tamrat, E., 1997. Magnetostratigraphie et magnetisme de sequences lacustres PlioPleistocene et Holocene d'Afrique Orientale (Ph.D. dissertation). University of Aix-Marseille III, France, p. 302.

Tamrat, E., Thouveny, N., Taieb, M., 1996. Magnetostratigraphy of the lower member of the Hadar Formation (Ethiopia): evidence for a short normal event in the Mammoth reverse subchron. Studia Geophysica \& Geodetica 40, 313e 335

Tamrat, E., Thouveny, N., Taieb, M., Opdyke, N.D., 1995. Revised magnetostratigraphy of the Plio-Pleistocene sedimentary sequence of the Olduvai Formation (Tanzania), Palaeogeography, Palaeoclimatology, Palaeoecology 114 273 e283

Tarling, D., Hrouda, F., 1993. The Magnetic Anisotropy of Rocks. Chapman \& Hall, London, p. 217.

Tauxe, L., Gee, J.S., Staudigel, H., 1998. Flow directions in dikes from anisotropy o magnetic susceptibility data: the bootstrap way. Journal of Geophysica Research 107, 17775e17790.

Walter, R.C., Manega, P., Hay, R.L., Drake, R.E., Curtis, G.H., 1991. Laser-fusion ${ }^{40} \mathrm{Ar} /{ }^{39} \mathrm{Ar}$ dating of bed I, Olduvai Gorge, Tanzania. Nature $354,145 e 149$.

Walter, R.C., Aronson, J.L., 1993. Age and source of the Sidi Hakoma tuff, Hadar Formation, Ethiopia. Journal of Human Evolution 25, 229e240.

Westphal, M., Chavaillon, J., Jaeger, J.J., 1979. Magnétostratigraphie des dépôts pléistocènes de Melka Kunturé (Ethiopie): Premières données. Bulletin de la Société Géologique de France 21, 237e241.

Zijderveld, J.D.A. 1967. AC demagnetization of rocks: analysis of results. In: Collinson, D.W., Creer, K.M., Runcorn, S.K. (Eds.), Methods in Paleomagnetism. Elsevier, Amsterdam, pp. 254e286. 